\title{
Aprender a ler entre cartilhas: civilidade, civilização e civismo pelas lentes do livro didático.*
}

Carlota Boto

Universidade de São Paulo

Correspondência:

Carlota Boto

Alameda Franca, 260 apto 102

01422-000 - São Paulo - SP

e-mail: carlotaboto@uol.com.br

\section{Resumo}

Este ensaio tem por objetivo identificar o lugar social ocupado pela cartilha de primeira leitura nos usos e costumes da história da moderna escolarização primária. 0 propósito do estudo é o de averiguar o entrecruzamento entre o livro didático e as práticas da escola primária, mediante a clivagem analítica do campo da História da Educação. Prescrição, constrição, controle e confronto, o manual didático de ensino das primeiras letras propõe-se a destacar o contexto do letramento como alternativa para a oralidade do mundo infantil. Com tal pressuposto, o trabalho aqui desenvolvido debruça-se sobre a produção didática de um intelectual português de meados do século XIX, Francisco Júlio Caldas Aulete, abordando especificamente a Cartilha nacional de sua autoria. Esse livro de ensinar a ler e a escrever propunha um ensino, a um só tempo, simultâneo, calcado no aprendizado paralelo da leitura e da escrita; e explicitamente contrário à prática da soletração - o que aproximava o modo de ensino prescrito por Caldas Aulete da marcha do que posteriormente se caracterizaria como método analítico de alfabetização. Finalmente, pode-se compreender que o estudo da Cartilha nacional - a despeito de seu caráter tópico - remete a aspectos sócio-históricos de singular relevância, posto que havia ali um rascunho nítido de um projeto de país: civilidade, civismo e civilização eram os dísticos que norteavam a proposta do ensino no rito inicial da escola primária.

\section{Palavras-chave}

Cartilha - Livro didático - História da educação - Alfabetização.

* 0 presente trabalho integra o Projeto Temático Educação e Memória: organização de acervos de livros didáticos, o qual - sob a coordenação da Prof ${ }^{\mathrm{a}}$. Dr ${ }^{\mathrm{a}}$. Circe Bittencourt - conta com o auxílio financeiro da Fapesp. 


\title{
Learning to read between primers: civility, civilization and civism through the lenses of schoolbooks
}

Carlota Boto

Universidade de São Paulo

\begin{abstract}
The present essay seeks to identify the social locus occupied by the literacy primer in the customs and practices of the history of modern primary schooling. The purpose of the study is to examine the intermingling between the schoolbook and primary school practices through the analytical cleavage of the field of History of Education. Direction, constriction, control and confrontation, the school manual for teaching literacy proposes to highlight the context of literacy as an alternative to the orality of the world of the child. Under such premise, this work investigates the didactic production of a mid-19 $9^{\text {th }}$ century Portuguese intellectual named Francisco Júlio Caldas Aulete, more specifically his Cartilha Nacional. That literacy primer proposed a teaching that was, at one and the same time, simultaneous (since all pupils should be taught together and indistinctly, as if they were one), founded on the parallel learning of reading and writing, and explicitly against the practice of spelling - a feature that brought his proposal close to the path later characterized as the analytical method of teaching literacy. Finally, one can understand that the study by the Cartilha Nacional - despite its topical character - points to socio-historical aspects of great relevance, given that one can find in that schoolbook a clear blueprint for a country: civility, civism and civilization were the motto that directed the proposal for teaching in the initial rite of primary school.
\end{abstract}

\section{Keywords}

Contact:

Carlota Boto

Alameda Franca, 260 apto 102 01422-000 - São Paulo - SP

e-mail: carlotaboto@uol.com.br

Primer - Schoolbook - History of education - Literacy.

\footnotetext{
* The present work is part of the Thematic Project entitled "Education and Memory: organization of schoolbook collections", which is coordinated by Professor Circe Bittencourt and is sponsored by Fapesp.
} 
É muito louvável o arranjo e a ordem que Augusto guarda em todas as suas coisas. Quando necessita de algum livro ou outro objeto, vai buscá-lo, e, depois de se servir dele, torna a pô-lo no seu lugar. É muito asseado no corpo e no vestido. Logo que se levanta, lava-se e penteia-se. É ele que escova o fato e o guarda. Quando escreve a lição, nunca suja os dedos com a tinta, nem deita borrões no papel. Amélia é o contrário de seu irmão. Nunca sabe onde tem os livros nem a escrita. É necessário que sua mãe lhe esteja sempre a repetir: Amélia, vai lavar a cara; vai pentear-te. Uma hora depois de a vestirem de lavado, já tem o fato tão amarrotado e sujo que é mesmo uma vergonha, e às vezes até com o seu rasgão. Anda sempre com os dedos cheios de tinta. Não faz escrita em que não deite pelo menos dois borrões. Que diferença de irmãos! Ele, na escola, premiado pelo professor com mui lindas estampas, e em casa pelos pais com muitos bonitos. Ela, pelo contrário, na escola repreendida pela mestra, e em casa pela mãe, e ameaçada já de a prenderem durante as horas de recreio num quarto escuro. (Francisco Júlio Caldas Aulete)

\section{Introdução}

0 professor primário não pode hoje falar em voz alta (está em desuso a idéia); mas certamente ele pergunta a si mesmo: devo ou não usar "a cartilha"; e por que devo ou não fazê-lo? Historiadores da educação interrogam o tempo que tomaram por seu desafio: como se poderá reconstituir o percurso das produções editoriais dirigidas à escolarização e das práticas da primeira leitura escolar? Por outras palavras, como proceder à reconstituição de alguma prática leitora e escrita mediante o estudo das cartilhas escolares? Finalmente, o individuo curioso poderia questionar: de onde vem a palavra cartilha? Muito provavelmente principiando por essa última questão - poder- se-ia dizer que o termo cartilha constitui um desdobramento da palavra "cartinha" que, por sua vez, era usada - em língua portuguesa desde o princípio da ldade Moderna, para identificar aqueles textos impressos cujo propósito explícito seria o de ensinar a ler, escrever e contar. Apresentavam usualmente o abecedário, a construção das palavras e suas subdivisões, alguns excertos simples com conteúdos moralizadores, quase sempre precedidos de excertos de orações ou de salmos, posto que a religiosidade era a marca daquele ensino primário que, pouco a pouco, se constituía. A palavra cartilha, que vem de cartinha, remonta, por seu turno, às situações mais corriqueiras e freqüentes: até o século XIX, boa parte (muitas vezes a maioria) dos textos escritos que as crianças traziam de casa para utilizá-los na escola como materiais de ensino da leitura eram manuscritos: dentre esses, as cartas eram uma fonte privilegiada... Muitos eram os meninos e meninas que, em Portugal, aprenderam a ler inicialmente mediante a leitura de cartinhas... À semelhança e por analogia, elabora-se - para os primeiros textos impressos com a finalidade alfabetizadora - a expressão "cartinha de leitura”. Daí vem à cartilha.

Outra pergunta acima formulada é aquela que se põe o historiador da educação: como efetuar a relação entre o conhecimento histórico das práticas de ensino e o livro didático (Bittencourt, 1993), explicitamente no caso das cartilhas? Porque a cartilha é, talvez, o compêndio escolar que permanece conosco por mais tempo. Remetendo-nos ao nosso próprio trajeto de vida, lembramo-nos do folhear de suas páginas, por vezes das cores das letras de cada lição, do formato das ilustrações, da textura das páginas, do suporte impresso que sustenta o texto. Passamos simbolicamente, simplesmente por percorrer aquele primeiro livro, da condição de analfabetos à de leitores. Nas cidades, lembramo-nos dos primeiros cartazes que fomos capazes de ler sozinhos (e em voz baixa) na rua. Tais recordações nos assaltam exatamente porque, desde então, jamais 
nos pudemos furtar à leitura; mesmo que desejemos fugir, somos por ela assaltados. Crianças, imaginávamos que era a cartilha quem nos ensinava, paulatinamente, a ler. Daí sua primazia entre lugares de memória.

0 professor primário, por seu turno, pergunta a si próprio: estarei obtendo uma prática de magistério mais crítica, mais progressista e mais eficaz simplesmente porque não uso a cartilha para alfabetizar meu aluno? Existe uma relação de causa e efeito entre o uso da cartilha e a fatal e inarredável situação de uma prática de ensino obsoleta, tradicional, ultrapassada? Os alunos construtivistas, dos tempos sem cartilhas, aprendem mais, melhor e em um tempo mais curto?

Evidentemente, embora herdeiro daquele tríplice questionamento, supramencionado, o presente estudo tem por objetivo refletir, do ponto de vista da História da Educação, acerca dos sentidos inscritos no texto de cartilhas. A hipótese desenvolvida é a de que o livro didático, por sua produção e pela amplitude de seu uso, deixa rastros emblemáticos para se pensar o tema da inscrição dos saberes da escola primária em sua constituição histórica, no âmbito da atmosfera mental das sociedades letradas. Com tal propósito, tomamos por recorte a situação portuguesa, e especificamente a produção didática de um renomado intelectual de meados do século XIX - Francisco Júlio - que a dada altura torna-se bastante conhecido no Brasil como título de seu próprio dicionário: Caldas Aulete, o qual, por longa duração, constituiu uma das mais renomadas dentre as obras de referência no gênero. 0 dicionário Caldas Aulete evidencia - por seu uso, por sua circulação e pela presença constante nos acervos das bibliotecas dos homens letrados deste país - o dinâmico processo de entrecruzamento entre culturas que, certamente, entre Portugal e Brasil - em algum momento - atingiu o campo editorial. Todavia, para além de seu dicionário, pouco se conhece do autor.

Francisco Júlio Caldas Aulete (18231878) foi professor da Escola Normal de Marvila, da Escola Acadêmica e do Liceu Central de Lisboa (Nóvoa, 2003, p.118). Pela proeminência de tais instituições, pode-se inferir que se tratava de um professor muito provavelmente destacado por sua formação. Como sujeito envolvido com a formação de educadores, Caldas Aulete dedicou parte de sua energia didático-pedagógica para a elaboração de material escolar, cujo uso poderia se constituir como um fator que, a um só tempo, viesse a tornar-se referência de apontamento para aprimorar a aula ministrada pelo professor e oferecer melhores condições de aprendizado aos alunos em distintos e sempre dinâmicos grupos-classe. A preocupação com o êxito no processo de ensino-aprendizado é bastante acentuada nos manuais escolares de uso didático produzidos pelo educador.

Nos anos 60 do século XIX, Caldas Aulete publica sua Grammatica nacional (Nóvoa, 2003, p.119); editando, posteriormente, em 1875, sua famosa Selecta nacional - curso prático de literatura portuguesa (Aulete, 1882). Explicitamente, sua produção denotava sua ocupação como homem de letras perante a formação de uma cultura erudita, no cômputo da norma culta na língua portuguesa. Era necessário formar o indivíduo para a construção do discurso e para o uso elaborado das combinações lingüísticas autorizadas pela gramática nacional. Além disso, seria oportuno que o cidadão estivesse hábil para identificar - mediante excertos da produção literária portuguesa previamente recortados, selecionados e compendiados - autores e construções lingüísticas que o aproximassem do que melhor houvesse sido produzido pelo campo da literatura, tomando por empréstimo palavras extraídas de obras consideradas de excelência, de obras dos grandes autores.

\section{Ensino inicial da leitura e da escrita em Portugal do século XIX: o estado da arte}

No ano de 1854, em artigo intitulado "Estudos sobre os diferentes métodos de ensino do ler e escrever" - publicado no periódico 
intitulado O Panorama -, J. M. Latino Coelho (1825-1891) destacava a precariedade na qual permaneciam as escolas do ler, escrever e contar, obstaculizando o próprio progresso da instrução no país. Latino Coelho era escritor, político, jornalista e um propagandista da causa da instrução popular. Dotado de uma singular cultura enciclopédica (Nóvoa, 2003, p. 371), publica alguns livros didáticos, que expressavam sua inquietação quanto ao que acreditava ser a carência de métodos e técnicas adequados ao ensino no país. Naqueles meados do século XIX português - ao que tudo indica - persistia a predominância do uso de abecedários e manuscritos para o ensino da leitura e da escrita, tal como ditava a tradição herdada do século XVIIl, naquilo que Rogério Fernandes (1994) identifica como "os caminhos do ABC". Com o fito de proceder à propalada regeneração do país tido já por decadente diante da situação européia, tratava-se - de acordo com os teóricos da educação - de valorizar a cultura letrada, impressa, tipográfica, como parâmetro essencial do processo de esclarecimento, mediante o ensino adequado dos procedimentos norteadores do aprendizado da leitura, da escrita e do cálculo.

Em artigo escrito para a Revista Universal Lisbonense, "Estado da instrucção primária no concelho de Alpedrinha no ano lectivo de 18481849”, F. A. Rodrigues de Gusmão (1849, p. 491) assinalava a carência de manuais específicos para uso do professor no preparo de suas aulas, na organização de sua rotina diária. Ao referir-se ao estado da instrução em conselhos atrasados do país, o autor expressa seu parecer crítico:

Consideramos a Instrução Primária por uma das suas faces: freqüência das escolas, ou extensão ou da instrução; é mister olhá-la por outra - aproveitamento dos alunos, ou intenção da instrução. É doloroso ter de expor, sobre este objeto, amargas verdades; obedecemos, todavia, aos ditames da nossa consciência, revelando-as. Os professores cumprem frouxamente seus deveres; com a irregularidade da paga das remunerações desculpam a sua negligência. Em verdade o Estado não tem direito a exigir dos professores bom serviço, se lhes não dá em tempo conveniente o ordenado, que lhes prometeu; é um contrato bilateral, que obriga reciprocamente. (...) Além disso, os professores dirigem-se no ensino por mero arbítrio; não têm instruções, que regulem a polícia e a disciplina das escolas, nem há quem as fiscalize convenientemente. Em todas as nações da Europa há manuais para mestres de meninos; em Portugal, infelizmente, ainda não se publicou este livro indispensável, no qual devem expor-se, além de outras noções que não mencionamos por brevidade, as matérias de ensino e maneira de ensiná-las; a classificação dos alunos; a distribuição das lições, e exercícios de Aritmética, de Gramática e Geografia, de História Sagrada e História Natural, por meio de estampas e objetos materiais, etc.; finalmente os principios gerais de educação física, da educação moral e da educação intelectual, que se consideram mais úteis a todos os pais de famílias e mestres, aplicando estes princípios à educação dos meninos. Se não se pagar pronta e regularmente aos professores; se não se lhes der instruções claras e positivas sobre a maneira de cumprir seus deveres; se não se definirem bem estes deveres, consignando-os em um diretório particular; se não houver, finalmente, quem superintenda os professores, visitando as escolas em épocas indeterminadas (...); debalde se fatigarão os nossos estadistas em organizar, e promover a instrução há de sempre mancar infelizmente. (Rodrigues de Gusmão, 1849, p. 491)

Nota-se aqui a preocupação do articulista com a inexistência de orientação para os professores a fim de traçar diretrizes em relação àquilo que se poderia entender como o conjunto dos "saberes elementares escolarizados" (Hébrard,1990, passim). Deseja-se prescrever também sugestões que impulsionassem a unidade da escola, tendo em vista dois objetivos 
matriciais: a eficácia do intuito de ensino das primeiras letras - o ler, o escrever e o contar além da observação de valores morais. Tratavase de um período marcado por intenso fervilhar de debate e circulação de idéias acerca do temário da leitura, da utilização pela escola do texto impresso; até para espraiar códigos de conduta profissional passíveis de conferir uniformidade à atuação do professor em sala de aula. Naquela altura, atribuía-se substantiva visibilidade aos jornais e periódicos, tidos por veículos estratégicos de divulgação da palavra escrita, e com ela da cultura letrada, "civilizada". Substituir a oralidade nas práticas culturais exigiria, aos olhos do tempo, o uso intensivo da imprensa, que aparecia aos contemporâneos como concorrente do livro.

Vista muitas vezes com entusiasmo, a imprensa, com todo seu apelo à leitura, poderia tornar-se, entretanto, veículo perigoso de irradiação e circulação de idéias más. É assim que autores da época, ciosos por acoplar instrução e virtude, nos próprios jornais onde escrevem, costumavam precaver seus leitores contra a leitura desavisada, espontânea, convidativa porque atraente... Submergir no mundo desconhecido do escrito poderia representar um ato de subversão da ordem e de questionamento das práticas corriqueiras e das instituições tidas por naturais. Por ser assim, convida-se o leitor-interlocutor a proceder à gesta da leitura reflexiva que, sob tal estatuto, exigia como imperativo o recorrente afastamento da atração exercida por leituras frívolas, em prol do que se supunha ser o estudo sério para formação de hábitos. Tal concepção do lugar social da leitura possibilitaria o pensar por si próprio, atividade derivada, no caso, da própria atitude de desconfiança perante as tentações exercidas pelo texto impresso, como veículo material do espraiar da ciência (Catani, 1990, passim). 0 progresso da civilização só poderia ser acatado se viesse acompanhado do esforço de moralização. Aqui estaria a obra precípua da escola e do ritual da alfabetização. Sob a mesma orientação, havia intenso entusiasmo com um jornalismo de cunho pedagógico, que pretendia a divulgação dos conhecimentos úteis, ${ }^{1}$ o que, por sua vez, coincidirá com a intensificação do processo de editoração de compêndios escolares.

0 livro escolar principia seu reinado nas escolas portuguesas. Verifica-se nesse período uma profusão de iniciativas que, ancoradas por suportes de textos didáticos, pretendiam trazer sistematização, eficácia, e mesmo cientificidade àquela escola até então cambaleante. Objetivava-se com isso altear a instrução como um dispositivo regenerador do atraso, capaz de atuar em direção da superação da decadência daquele reino, outrora glorioso. Acerca da produção editorial de textos elaborados para o uso da escola, já anotava o Relatório Anual de Inspeção às Escolas, elaborado pelo Conselho Superior de Instrução Pública, no ano letivo de 1856-1857:

É notável a variedade de livros elementares que se usam nas escolas, e não menos a impropriedade e pouca correção com que muitos deles são escritos; e muito conviria que o governo de V. M. tomasse providências para a melhor escolha e uniformidade de catecismos e compêndios, facilitando-os a todos por um preço módico e mandando-os fornecer gratuitamente aos meninos pobres. (Gomes, 1985, p. 246)

É notória a alusão às obras escolares também na imprensa da época, que ora divulgava, ora comentava o conjunto de manuais, cartilhas e abecedários amplamente analisados.

1. Nessa trilha, destacar-se-ia o pioneirismo de Alexandre Herculano, 0 idealizador do periódico 0 Panorama. Herculano pretendia que a mesma revista assumisse o lugar explícito de divulgadora de conhecimentos úteis, julgando que sua primordial tarefa seria a de derramar o conhecimento sobre camadas pouco letradas da população. Nessa medida, o tom enciclopédico da iniciativa deixava entrever sua herança da atmosfera das Luzes, onde o lugar da imprensa passa a ser pensado especificamente como a estratégia privilegiada de formação da opinião pública esclarecida; ou de um espírito público. 0 editorial do dia 6/1/1837 declara explicitamente 0 objetivo daquele periódico: "derramar a instrução, fazendo descer a literatura e a ciência ao nível das inteligências comuns: para isto era preciso conhecer primeiro o que o espírito do povo comportava de alimento intelectual: era preciso saber qual o estado e a tendência da civilização entre nós" (0 Panorama, 6/1/1837). 
Como exemplo, cita-se artigo de José de Torres (1853) - intitulado "instrução elementar" e publicado no volume $\mathrm{X}$ do periódico $O$ Panorama, no ano de 1853. 0 autor, à época, era colaborador d' $O$ Panorama e nesse jornal costumava escrever sobre temas atinentes à educação, destacando a necessidade de se melhorar a qualificação do professorado, como dispositivo essencial para fazer florescer a escola primária. José de Torres (1853) sublinha também o lugar didático e a relevância pedagógica do compêndio escolar, como instrumento privilegiado para uso do professor; especialmente voltado para o bom preparo e ordenação de suas aulas. Daí a necessidade de se proceder com atenção e suficiente cuidado para a escolha daquilo que Torres (1853) nomeia livro da infância.

De tantas cartas, de tantos expositores, de tantos métodos facílimos, que por aí andam com pregão mercenário desafiando a boa fé do público descuidado, qual deles, qual delas, pode dizer-se que não haja suplício da infância, banco de areia em que este pobre baixel se enterra, se estorce, se desconcerta, e que só com a força de embates e choques violentos se transpõe? E nem o perigo deste quase naufrágio é tudo! Feridas insanáveis ficam depois de tanto bater e combater em vão: fica a impaciência, a desafeição ao estudo, impressões que, em ânimos tenros, se fixam e consubstanciam facilmente, e que decidem da sorte de toda uma vida, de toda uma geração talvez! (Torres, 1853, p. 286)

À partida, José de Torres refere-se ao malogro dos métodos e materiais utilizados à época para a alfabetização por aquelas que eram tidas como as melhores e mais utilizadas das cartilhas editadas em Portugal. Alude-se explicitamente - ainda que para exarar parecer crítico - à Grammatica elaborada no século XVI por João de Barros (1996), ao livro de ensino da leitura intitulado $O$ expositor portuguez, de autoria de Luiz Francisco Midosi (1846) e ao Methodo facillimo para aprender a ler tanto a letra redonda como a manuscrita no mais curto espaço de tempo de autoria de Emílio Acchiles Monteverde (1859). Objetivando delimitar os fundamentos precisos de uma cultura especificamente escolar, o autor dialoga não apenas com a produção editorial de seu tempo, mas também, ao que parece, com a política que regia o universo do livro escolar. Sugere, pois, na seqüência, que o primeiro livro de leitura fosse um tratado de deveres, assumindo com isso o ofício de moralização da escola como atitude voltada para a facilitação do aprendizado. 0 caráter enciclopédico do texto seria também recomendado, sob a condição de vir acompanhado de uma linguagem acessivel ao universo simbólico da infância. Mais uma vez, indiretamente, Torres alude à obra de Monteverde, desta vez não à cartilha, mas ao Manual encyclopedico para uso das escolas d'instrução primária (1843). Este era, prescrito por Monteverde, como o livro didático subseqüente à sua cartilha. Em ambos os casos, eram duas das mais lidas obras escolares em Portugal do século XIX. As palavras assinaladas com maior acento no discurso de José de Torres indiretamente tomando como interlocutora explícita a produção didática de Monteverde - revelam o debate e a disputa de territórios no tocante aos protocolos editoriais voltados para a produção editorial didática daquele tempo:

Não conviria que o primeiro livro com que a puerícia fizesse conhecimento fosse um tratado de deveres, que pela clareza da substância e do formulário facilmente se lhe imprimisse n'alma? Até aqui, até este livro leitura simples. Em seguida outra transição; já estudo em enciclopédia manual, que tanto obrigasse a gramática, aritmética geografia, cronologia e história, como aos demais elementos de ciências naturais, morais e filosóficas; e então a instrução primária teria, em tempo mais curto e com trabalho mais leve, alguma coisa de real e significativa na civilização e adiantamento social. Para fazer este livro de deveres, e a 
enciclopédia que ainda não temos (pois os que se apontam tais são de erudição demasiadamente pretensiosa, e até muitos mestres haverá que os não entendam) não faltam homens competentes: falta o favor com que mais se acende o engenho. Prêmio de duzentos mil réis estabeleceu aos compêndios o decreto de instrução pública de 20 de setembro de 1844; mas nem ainda apareceu programa, nem se abriu concurso para essa tísica remuneração! Não há de ser assim que iremos sentar-nos no pantheon do mundo! Como? Se nem diligência dos altos, nem favor aos que debaixo trabalham! Quereis saber o que a academia francesa faz para aproveitar e exercitar os bons espíritos? Até a umas leiturinhas, historietas, conferiu o prêmio de seis mil francos...! Aprendei dos outros e cá tereis o que eles têm. (Torres, 1853, p. 286)

\section{A língua materna como fator imprescindível de identidade nacional}

Júlio Caldas Aulete (1823-1878), natural de Lisboa, colega e amigo de José Maria Latino Coelho (1825-1891), escreve com ele sua Enciclopédia das escolas, fora professor da escola normal primária de Marvilla, da Escola Acadêmica e do liceu de Lisboa, obtendo como se vê - intensa experiência prática no exercício do magistério. Seus estudos prediletos versavam também sobre instrução primária popular. Foi deputado às Cortes durante várias legislaturas e em sua carreira obteve aprovação do Conselho Superior de Instrução Pública para muitas de suas obras; dentre as quais destacaram-se a Selecta Nacional: curso pratico de litteratura portugueza e a Cartilha Nacional: methodo legographico para aprender simultaneamente a ler, escrever, ortographar e desenhar. Além disso, Caldas Aulete organizou um novo e rigoroso dicionário de língua portuguesa; o qual teria sido muito usado também no Brasil até meados do século XX. Sua atuação como educador era reconhecida e provavelmente valorizada pelos poderes constituídos à época, posto que já o Relatório de Inspeção dirigido às escolas públicas durante o ano letivo de 1866-1867 (MR 1056) indagava explicitamente dos professores quanto ao método de ensino adotado se estes se valiam ou não do método legográfico, o qual, por sua vez, estaria em Portugal - como se - disse, representado pela Cartilha nacional.

0 Relatório de Inspeção dirigido às escolas do Estado, que havia sido elaborado em 1866, impresso pela Imprensa Nacional, continha um item nomeado "regimen, disciplina e polícia da escola” (MR 1056). Ali havia espaço para o professor pronunciar-se quanto aos métodos e aos modos de ensino. No quesito relativo ao "método de ensinar a primeira leitura", constavam as seguintes alternativas, que vinham já explicitadas: "soletração antiga; soletração moderna; silabação fônica; método português; método legográfico". A Cartilha de Caldas Aulete era, em Portugal, muito provavelmente a única que, na ocasião, aludia ao dito "método legográfico”. Além dessa referência, portanto, explícita, havia outras, particularmente na folha reservada para "livros usados pelos alunos com a declaração do número de alunos que usam deles". Dentre os onze livros ali previstos, existia, ainda, a Encyclopedia das escolas de instrucção primária que Caldas Aulete elaborara em co-autoria com Latino Coelho. Isso de alguma forma representava a boa inserção política e fácil trânsito do autor, como homem público, no Conselho Superior de Instrução Pública.

A Selecta nacional: curso pratico de litteratura portuguesa (Aulete, 1882) era uma coletânea, dirigida ao curso secundário, destinada essencialmente a exercícios de leitura, de análise e de composição, como o próprio autor declara na Introdução. Procura expor para o aluno trechos verdadeiramente selecionados dos grandes escritores, que teriam brindado com suas obras a própria língua portuguesa, no parecer de seu tempo. Ao lê-los, o estudante poderia, a um só tempo, tomar conhecimento do assunto 
e fruir o estilo, o que o ajudaria a se expressar melhor, fosse verbalmente, fosse por escrito. Ninguém melhor do que o próprio autor para definir sua obra e, na seqüência, traçar diretrizes acerca do método que se deveria empregar ao adotá-la. Caldas Aulete sugere, em todos os níveis, o que chama redação oral:

Estamos convencidos de que o ensino da língua materna se deve começar nas escolas elementares com o ensino do ler, graduando-se pela seguinte ordem: ao estudo do ler e do escrever, se há de associar o de ortografar; ao da leitura corrente as noções de gramática, os exercícios de redação oral e as breves composições por escrito, em estilo singelo, tão recomendadas nas instruções do governo aos professores. Para este fim, coordenamos três livros que formam o sistema completo deste nosso pensamento: 1) Um livro que intitulamos Método legográfico ou Cartilha nacional, em que se ensina simultaneamente a ler, a escrever, a contar e a ortografar, por um processo tão natural e fácil, que em muito pouco tempo as crianças com grande aprazimento adquirem a prática destas disciplinas. 2) Uma Gramática, que também denominamos Nacional, dividida em duas partes, sendo a primeira destinada para as escolas primárias e a segunda para uso dos liceus. Neste compêndio se encontram também os processos que o professor há de empregar no estudo das palavras e das frases, e nos exercícios de análise e composição. 3) Uma Seleta dividida em três volumes, contendo o primeiro volume, grande porção de trechos apropriados, pela simplicidade do estilo e aprazivel do assunto, para os exercícios de leitura, de redação oral, de composição por escrito e de análise nas escolas elementares; ficando os trechos de estilo ornado contidos no presente volume, e os excertos do segundo e os do terceiro, para o estudo da língua materna nos liceus. 0 modo por que se hão de fazer os exercícios de redação oral nas escolas elementares é o seguinte: escolhido pelo professor para a lição de leitura de um trecho, que deverá ser dos mais fáceis e dos que as crianças possam ter maior desejo de ler, o professor fará repetir a leitura dele tantas vezes quantas sejam necessárias para o pronunciarem com clareza e inteligência. Depois convidá-las-á a que refiram oralmente o assunto do trecho. 0 professor há de animá-las e auxiliá-las muito neste exercício. Quanto maior o número de palavras e frases empregarem do texto escolhido, mais profícuas serão estas narrações. 0 professor nunca se deve mostrar enfadado de ouvir seus juvenis expositores, para assim conseguir que percam certa timidez que, em geral, as crianças manifestam quando têm de se referir a algum fato perante pessoas que julgam superiores. Devem-se se escolher sempre trechos, que, pelo assunto e pela elegância do estilo, as exaltem e entusiasmem, e lhes desenvolvam veementes desejos de serem grandes pela virtude e pelo trabalho. Tirai das mãos inocentes das crianças essas enciclopédias pedantes que elas não entendem, e que não servem mais que para lhes criar o tédio e o aborrecimento à escola e ao estudo. (Aulete, 1882, p. IX-XI)

Dirigida aos professores e aos estudantes do curso secundário, a mesma referida Seleta nacional (Aulete, 1882) apresentava-se em sua folha de rosto como obra direcionada e aprovada pelo governo para uso das escolas primárias e dos liceus. Na introdução do trabalho, contudo, Caldas Aulete pontua que o público ao qual mais explicitamente se dirigia aquele compêndio era contemplado pelas cadeiras de língua e de literatura portuguesa dos institutos de ensino secundário, posto que o texto teria sido inclusive elaborado em conformidade com os programas dirigidos a esse nível da escolarização. Ressaltando sempre a necessidade de conferir um caráter gradual do ensino, Caldas Aulete conclui a introdução do 
seu livro com a divisa que, segundo ele, deveria ser o ponto de honra de qualquer professor de língua materna: "gramática pouca, exercícios muitos” (Aulete, 1882, p. XII).

A Selecta nacional constituía um agregado eclético de parábolas do evangelho, contos, narrações morais, descrições extraídas de romances clássicos, definições de sentimentos dadas pelos grandes escritores da língua, lendas, alegorias, biografias de vultos e tipos nacionais, provérbios, pensamentos e sentenças, além de inúmeros outros ditos de religião, de filosofia, de moral e de ciência. Além disso, havia também temas como os dos tipos nacionais - sendo aqui descrito, com autoria de Latino Coelho, o janota de Lisboa como um dos tipos nacionais. Finalmente, existiam duas seções cujo objetivo era o de veicular textos biográficos tidos como exemplares de conduta para as novas gerações: Marquês de Pombal, Padre Antônio Vieira, Júlio de Castilho, José Bonifácio de Andrada e Silva e outros vultos cuja história de vida deveria ser apreendida como modelo e referência para as gerações vindouras. 0 livro didático era então criteriosamente dividido, de maneira que as unidades constituissem verdadeiramente eixos temáticos, que facilitassem ao professor o uso didático do compêndio.

Após a morte de Caldas Aulete, a reimpressão da obra passou a contar com um prólogo de Thomas de Carvalho, intitulado "Juízo crítico da Selecta nacional de literatura”. 0 comentarista destaca, naquela oportunidade, a propriedade dos trechos selecionados por Caldas Aulete e recorda que era intenção do trabalho e do governo, quando o aprovou, a existência de um cunho moral extremamente presente nos trabalhos escolares. Recordando que o livro seria apropriado independentemente da idade do seu leitor e do grau de instrução com que este efetivamente contasse, Carvalho comenta que a instrução graduada era aquilo de que mais necessitava a escola portuguesa.

Assim, pois, o crítico ao compor uma Seleta não há de simplesmente ser um jardineiro, mas um botânico. Cumpre-lhe não confundir as espécies, para tecer o seu florilégio. Além disto, se o livro tem de servir nas escolas, outra preocupação maior estará presente ao espírito do coletor, para não incutir no ânimo dos alunos inexperientes nem erros de ciência difíceis de extirpar e esquecer posteriormente, nem erros de moral que lhes pervertam e corrompam o coração. 0 governo, facultando ao povo os meios de se instruir, não pretende somente abrir-lhe e ornar-lhe a inteligência, mas ensiná-lo a respeitar e venerar as leis divinas e humanas (Carvalho apud Aulete, 1882, p. V) ${ }^{2}$

0 primeiro excerto de autoria de Antônio Feliciano de Castilho era assim intitulado: "preceitos para escrever em bom portuguez" (Castilho apud Aulete, 1882, p. 1). Ali, logo a princípio, dizia-se que a língua que falamos e que devemos escrever é composta por uma tríplice interação entre o vocabulário, a gramática e os princípios da retórica:

(...) as palavras, o seu mútuo e legítimo acordo e o privativo modo da sua colocação; vocabulário, gramática e retórica inicial. Ministra a primeira os materiais com que se há de edificar o discurso; a segunda é a mão de obra que os liga e trava; a terceira a arquitetura e ornamentação, que, pela maneira de colocar os materiais, realça em cada um, pelas suas relações com os outros, ora a força, ora a graça, ora a graça e a força juntamente. Destas três partes constitutivas da linguagem, a mais incontrastavelmente progressiva é o vocabulário. Crescem as ciências, cresce com as ciências; crescem as artes, cresce com as artes; crescem o luxo, o comércio, a sociabi-

2. Outro livro que compunha esse mesmo modelo de coletânea de trechos selecionados dos clássicos era o Logares selectos dos classicos portugueses nos principais generos de discurso em prosa, organizado por A. Cardoso Borges de Figueiredo (1879). Esse livro, que havia alcançado, em 1883, sua $18^{a}$ edição era, entretanto, mais elaborado que seu homônimo de Caldas Aulete, por pretender discorrer sobre os variados gêneros de discurso: familiar, epistolar, histórico, didático, descritivo, oratório; em suas distintas características e propriedades. 
lidade, os vícios, as virtudes; com tudo isso e de tudo isso cresce. 0 vocabulário é a fotografia completa do saber de um povo; é o psicógrafo que indica e deixa registrados os sucessivos graus por onde o espírito foi ascendendo. (Castilho apud Aulete, 1882, p. 1)

No campo já dos usos do vocabulário e da gramática para efeito retórico destacam-se os trechos explicitamente moralizadores, muitos deles redigidos pelos expoentes da escrita na língua portuguesa. De autoria, portanto, do Padre Antônio Vieira, podemos encontrar - sobre a mentira - o seguinte:

A mentira é filha primogênita do ócio. Vede como se forma dentro em vós mesmo este monstruoso parto. Quem está ocioso, não tem mais o que fazer que por-se a imaginar: da ociosidade nasce a imaginação, da imaginação a suspeita, e da suspeita a mentira. Quem trabalha, trata da sua vida, quem está ocioso trata das alheias. Quem trabalha, como cuida no que faz, fala verdade; porque diz as coisas como são. 0 ocioso, como não tem o que fazer, mente; porque diz o que imagina. É a imaginação no ocioso como a serpente de Eva. Estava ociosa Eva no paraiso, entrou a serpente coleando-se mansamente sem pés, mas com cabeça; começou pela especulação e acabou pela mentira... Quantas vezes se diz do honrado e da honrada, do inocente e da inocente, o que nunca lhe passou pela imaginação? Mas basta que o maldizente o imagine, ou o queira imaginar, para o por na conversação e na praça, e o afirmar com tanta certeza, como se o lera em um Evangelho. Deus vos livre de tais línguas e muito mais de tais imaginações. (Vieira apud Aulete, 1882, p. 320-321)

\section{A Cartilha nacional de Caldas Aulete: saberes e métodos}

Foi em 12 de Junho de 1850 que Francisco Júlio Caldas Aulete dirigiu um ofício ao secretário do Conselho Superior de Instrução Pública - José António Amorim - explicitando o que entendia ser a novidade da obra que pretendia fazer aprovar por aquele órgão. Tratavase de um trabalho dirigido às escolas, originalmente sob o título Livro da infancia ou methodo facil e racional para ensinar a ler. Na verdade segundo consta do manuscrito de apresentação da obra - aquela cartilha de ensinar a ler realmente fazia parte de um projeto mais amplo do autor; uma coleção que - nos termos do ofício - ele intitularia Biblioteca das escolas primárias, e que deveria, em seu conjunto, contemplar compêndios voltados para os diferentes níveis de aprendizado na instrução primária. 0 livro que então apresentava ao juízo crítico do Conselho Superior de Instrução Pública era na verdade o primeiro da pretendida série. Aquele autointitulado Primeiro livro da infância ensinaria, portanto, os primeiros caminhos do ato de ler "por um método fácil e porventura racional, proscrevendo como pernicioso o sistema até aqui seguido em todos os livros que para a primeira instrução da infância se tem adotado em Portugal" (Aulete, 1850).

Caldas Aulete reconhecia e enfatizava que seu método de ensinar a ler e escrever partia do desejo de suprimir a soletração do processo da alfabetização. Para isso, já bem antes de João de Deus, dava algumas modificações sonoras às vogais por meio de acentuação variada, embora não partisse - como mais tarde faria o poeta - do sentido da reunião de vogais entre si, mas da sonoridade que essa aliança traria, no sentido de haver a referida junção daqueles sons simples. ${ }^{3}$ Para além disso, todavia, Caldas Aulete enfatizava a necessidade de se obter paralelamente a eficácia no processo de ensino-aprendizado da leitura e da escrita; a uma só vez:

0 primeiro livro da infância dividi-o em duas

3. “iu; io; ái; áe; áu; áo; éo; êu; óe; ôi; êi; õu” - Era assim que vinham apresentadas as vogais reunidas na cartilha que posteriormente Caldas Aulete publicaria (Aulete 1873). 
partes. A primeira - o Silabário, é propriamente a cartilha aperfeiçoada, metódica e despida de todas as superfluidades e de todos os absurdos que publicam nos livros deste gênero na nossa pátria. Comecei dando às vogais as diversas modificações de sons de que são susceptíveis, procurando acostumar as crianças a pronunciarem aquelas diversas modificações logo desde os primeiros rudimentos da leitura, ao contrário do que se pratica geralmente, fazendo ler sempre o "a" que tem duas modificações distintas de som, de uma maneira uniforme; o "e" que é susceptivel de três modificações sempre com um som invariável e o mesmo a respeito do "o". Julguei acertado substituir entre nós o uso da leitura sem soletração, ao método velho e vicioso que só poderia invocar para a continuação da sua tirania nas escolas, a autoridade de uma rotina longamente seguida. Expliquei depois o modo de ler as consoantes duplicadas e as consoantes compostas; e finalmente o valor acidental que podem ter certas consoantes quando se acham em certas combinações com outras consoantes ou com vogais. Na segunda parte, a que dei o título Leitura Corrente, acham-se algumas sentenças morais extraídas da Santa Escritura, nas quais os alunos poderão achar escrita para ler - como se diz vulgarmente - por cima, ou sem soletrar. Eis aqui a razão por que chamei a esta segunda parte do livro Leitura Corrente. 0 aluno não há de soletrar a palavra juntando as letras para formar as sílabas, e estas para produzirem palavras. Há de ao contrário ler cada sílaba de uma só vez deixando apenas um pequeno intervalo entre a pronunciação de uma e da seguinte. (Aulete, 1850)

Caldas Aulete mencionava também que a introdução de seu livro era expressamente dirigida aos professores, explicando aos mesmos como proceder em sala de aula para adotar "cabalmente o mecanismo do método sem soletração”. De maneira protocolarmente elegante, dizia submeter sua proposta pedagógica ao douto parecer do
Conselho Superior de Instrução Pública. Dirigia, assim o ofício ao secretário do mesmo Conselho, procurando persuadi-lo da relevância e do acerto de suas opções teóricas e metodológicas:

(...) Para tornar a leitura mais fácil, entendi que as letras dobradas se deviam sempre considerar como reunidas numa só sílaba e não divididas uma da outra. Assim, a palavra attento ensinei a fazer a decomposição deste modo - a-tten-to - e não at-ten-to como pediam as razões etimológicas da língua. E julgo que é este método tanto mais de aceitar quanto é sabido que em todas as línguas vivas se decompõe as palavras por este modo. Assim o praticam os franceses, assim os ingleses e os alemães como se convence do seu livro de leitura... Prestando a devida homenagem aos talentos a quem está encarregada a suprema inspeção do ensino nacional, espero que o Conselho Superior de Instrução Pública se dignará de receber o trabalho que ofereço à sua douta censura, do qual mandei fazer uma pequena edição, que quase se pode dizer que tem por fim servir de cópia a limpo; para que, comunicando-se-me todas as observações e emendas que houver a fazer se possa, inutilizando esta, fazer uma edição digna da aprovação do Conselho Superior de Instrução Pública. (Aulete, 1850)

Para que a leitura pudesse identificar e ao mesmo tempo ultrapassar os limites da sílaba, ele as dividia na própria palavra por um pequeno intervalo, que auxiliava o aprendiz a reconhecer o som e apreender simultaneamente o sentido da palavra e da frase. ${ }^{4}$ Nota-se visivelmente a prio-

4. Posteriormente, a Cartilha nacional de Caldas Aulete apresentaria as frases sem desmembrar as palavras ou as sílabas, divididas realmente por aquele pequeno intervalo a que se referia o autor no ofício ao Conselho Superior da Instrução Pública. De qualquer maneira, o êxito da supressão da soletração pareceria pela notoriedade ganha pela mesma cartilha já inconteste. Note-se que a lição do "p" e do "t" vinham já seguidas pela tentativa de formação das frases, exatamente como 0 autor teria anteriormente indicado. Então, escrevia-se o seguinte, da maneira expressa a seguir: "O pi pi papôu a pápa na pá de pão ao pé do pa pá. //0 pá té ta do Ti to me ttêu o tó tó no lêi to da ti ti" (Aulete, 1873). 
ridade dada ao tema do método, pelos termos do ofício com que Caldas Aulete apresenta ao Conselho Superior de Instrução Pública o livro que acabara de escrever. Notoriamente, como se viu, as questões concernentes à didática e às metodologias do ensino passariam a ser o eixo temático do debate educativo em Portugal daqueles anos 50 do século XIX.

Caldas Aulete - não pretendendo exatamente inovar quanto à exposição do conteúdo ou dos saberes escolares veiculados por seu compêndio didático - expressava absoluta convicção de que sua cartilha era pioneira quanto ao método: havia ali assinalada uma nova forma de se proceder ao ensino das primeiras letras. Abolia-se a soletração; o aprendizado viria pela sentido expresso na relação entre significante, signo e significado. Aprendia-se a palavra, para em seguida decompô-la em suas partes. 0 aprendizado do som das letras vinha como efeito correlato ao aprendizado do sentido da palavra lida. Além disso, propunha-se - com ousadia para a época - o ensino paralelo da leitura e da escrita; propiciando, de tal maneira, procedimentos e técnicas capazes de habilitar o professor para o ensino simultâneo - mediante o qual todos os alunos aprende-riam, em princípio, ao mesmo tempo. Sendo assim, o professor, em sua exposição, apresentaria a matéria a todos como se falasse dirigindo-se a um só. Caberia, pela cartilha, orientar o professor - passo a passo no que ele deveria fazer. 0 uso do livro didático vinha, para Caldas Aulete, agregado a todo um roteiro prescritivo de normas e de protocolos de leitura que deveriam ser apreendidos pelo professor; e dos quais, em larga medida, dependeria o êxito do processo do ensino-aprendizado.

A estratégia de pautar o aprendizado das primeiras letras prescindindo do clássico e tradicional processo da soletração era o que, ao fim e ao cabo, daria razão ao reconhecimento da originalidade e ao êxito da posterior Cartilha nacional: método legográfico para aprender simultaneamente a ler, escrever, ortographar e desenhar. Vê-se assim que, quer nos debates intelectuais, quer nas polêmicas encetadas pela imprensa, quer nos relatóri- os de inspeção, a mesma tendência apontaria os anos 1850 como o tempo dos métodos e das técnicas. Como nunca, a Pedagogia ia ganhando ares e pretensão de ciência.

Caldas Aulete - no Directorio que integrava a sua Cartilha nacional de ensino simultâneo da leitura e da escrita - dirigia-se aos professores e procurava fixar diretrizes que dessem a eles parâmetros de condução das aulas e de orientação para o ensino do ler e do escrever. Assim, o autor pedagogicamente prescrevia técnicas e métodos - rotinas e rituais do ensino em salas de aulas... Procurava expor, antes de tudo, a necessidade de o educador incentivar a fala da criança:

(...) conversai com as crianças para as exercitar a falar, já que as famílias descuram este importante ensino que é uma das causas dos alunos fazerem tão pouco progresso nas escolas públicas... A propósito de tudo, explicai tudo. Fazei com que as crianças na escola respirem a moral e a ciência, com a mesma facilidade com que respiram e absorvem o ar e a luz. No desenvolvimento intelectual das crianças, não deis preferência a nenhuma faculdade, todas vos devem merecer igual cuidado... Empregai sempre para com as crianças uma linguagem fácil, clara e amena. As formas austeras, o estilo demasiado científico e dogmático devem ser absolutamente banidos das escolas elementares, como contrário ao bom ensino. Finalmente tornai quanto possa ser a escola um lugar atraente, alegre e de prazer. (Aulete, 1873) 5

Indicam-se alguns exercícios para os mestres que adotassem o ensino pelo método legográfico, cuja inovação consistia - como já se observou supra - em ensinar a um só tempo o ler e o escrever. Na verdade, partia-se do

5. Não foi possível anotar diretamente as páginas do livro didático de primeira leitura de Aulete, (1873 , $4^{a}$ edição), pois não há qualquer indicação de numeração de páginas. Por tal razão, nesta e nas demais notas referidas ao dito compêndio, não haverá registro de paginação. 
pressuposto de que o ensino combinaria os elementos da leitura oral e da transposição imediata pela cópia e, logo depois, pelo ditado. Entendia-se que a leitura representaria, por meio dos sons, a linguagem escrita. Havia, portanto, que treinar ao máximo essa identificação dos sons pelo exercício de oralização da leitura compreendida. Note-se como o Directorio indicava para o professor o ensino das frases:

$1^{\circ}$ processo: 0 professor escreverá uma frase no quadro preto ou numa ardósia, ou em papel; em seguida le-la-á em tom natural, como se fosse falada. Cada aluno as repetirá no mesmo tom, com o fim de não adquirir o vício de cantarolar. Depois fará ler soletradamente cada uma das palavras de per si sílaba por sílaba. Articulando as consoantes isoladamente como fica ensinado na lição segunda, isto é, em voz baixa, como se fossem seguidas de um "e" mudíssimo. $2^{\circ}$ processo: 0 professor ensinará a escrever essa frase no quadro preto ou nas ardósias. $3^{\circ}$ processo: 0 professor ditará essa frase, e os alunos hão de escrevê-las de cor. Estes serão os processos a seguir para o ensino das demais frases. 0 professor ordenará aos alunos que expliquem as frases que lerem ou os vocábulos que julgar mais próprios para os exercitar a falarem. (Aulete, 1873)

A sistematização do processo supunha, portanto, a escrita do professor no quadro negro, de onde todos o veriam. Para atrelar o ensino da leitura e da escrita, após ele ter escrito a letra " $\mathrm{i}$ " e recordado às crianças que se tratava do "i" de i-da ou do "i" de ilha, os alunos deveriam repetir o som e memorizar o traçado da letra. Em seguida o professor chamará uma criança à lousa para que ela escrevesse a letra aprendida. Chamaria um por um até que todos vissem uns aos outros e o fizessem por si. Finalmente o professor ditaria a letra que os alunos deveriam reproduzir nas suas específicas ardósias ou no papel - de cor. Logo, havia um percurso imediato em cada lição, estruturado mediante etapas que se traduziam por três momentos, desdobrados um do outro, e diretamente relacionados à aula:

(...) no primeiro processo se ensina a ler; porque a leitura é a arte que trata de representar por meio de sons a linguagem escrita. No segundo processo aprende-se a escrever; porque a escrita ensina a fazer as letras com que se representam as palavras que constituem a linguagem escrita. No terceiro processo aprende-se a ortografar; porque a ortografia é a arte que ensina a representar graficamente a linguagem falada. (Aulete, 1873)

Tratava-se indubitavelmente de compor uma rotina pedagógica que possibilitasse a instalação do ensino simultâneo. Mesmo assim, procedimentos herdados do modo de ensino mútuo eram também aproveitados quando Caldas Aulete indicava o aproveitamento de alguns exercícios que deveriam ser dirigidos em pequenos grupos por decuriões - ou monitores - treinados para multiplicar o conhecimento entre os colegas de turma.

0 decurião deveria agir como exemplo e como auxiliar do ensino. Cabia a ele ensinar a postura ao iniciante: como se sentar, como pegar na pena, como colocar a tinta, como debruçar-se sobre o papel, como exercitar a caligrafia e a disciplina escolar... 0 decurião mostrava enfim a normatividade da escola e deveria - também ele - ser copiado no que ali ditava sobre os comportamentos. 0 traçado das letras também era um aspecto acerca do qual existiriam regras a serem criteriosamente observadas. Para a prontidão do aluno para a escrita, a Cartilha nacional apresentava também exercícios de desenho, a estampa livre a propósito das diferentes lições do compêndio, figuras geométricas e serem copiadas e traçados de linhas retas e curvas para preparar exercícios caligráficos. A Cartilha recorda aos alunos - e aos professores - de que o exercício da escrita que se segue à atividade da leitura e dela se desdobra requer um vasto esforço de discipli- 
na, de autodomínio e de constrição corporal. Por tais razões, havia gestos a serem minuciosamente observados nesse propósito civilizatório de uma escola intrinsecamente moralizadora e reguladora da transformação das constrições externas em um cauteloso e inconsciente processo de autodomínio (Elias, 1993, passim). Cabia a corpo ser suficientemente adestrado enquanto veículo dirigido pela mente exercitada. Tal mecanismo requeria perseverança e árduo treinamento:

$1^{\circ}$ processo: 0 decurião ensinará a cada um dos seus alunos a pegar na pena e a exercitar os dedos no movimento necessário para a formação das letras e a ter o corpo direito numa posição natural. 20 processo: 0 decurião ensinará a seguir com um ponteiro ou pena seca as vogais “i”, “u”, “o”, “a”, “e”, que se acham no princípio desta lição. Isto com o duplo fim não só dos alunos adquirirem o hábito de pegar na pena e de moverem os dedos convenientemente, mas também de fixarem mais na memória a forma das letras. $3^{\circ}$ processo: 0 decurião ensinará a escrever em papel ou nas ardósias com um lápis ou pena molhada em tinta estas mesmas letras. E este processo se empregará para o estudo das outras letras e palavras. 0 decurião durante este exercício há de repetir aos alunos os seguintes preceitos:

- As letras devem guardar a mesma distância, a mesma inclinação e a mesma igualdade nos grossos e nos finos.

- As hastes no cursivo hão de ter duas alturas do corpo da letra, exceto o " $t$ " que terá uma só altura.

- As palavras hão de se separar umas das outras com o intervalo de uma letra, no cursivo um "m" no bastardo um "o".

- A pena não deve ser muito apertada nos dedos.

0 decurião há de por todo o cuidado para que os alunos conservem sempre as suas escritas muito asseadas, repetindo-lhes que um papel, para ser bem escrito, deve atingir a dois fins: ser muito legível e agradável à vista. (Aulete, 1873)

0 traçado das letras dependia da postura do corpo; exigia a coordenação motora fina. Crianças mais familiarizadas com o papel o lápis no ambiente familiar, de pronto, teriam, muito provavelmente, maior familiaridade. As crianças canhotas sofreriam. Deveriam escrever com a mão direita. Tratava-se da pena e do tinteiro. Caso o menino teimasse em seguir sua orientação natural de canhoto, o papel ficaria todo borrado; seus dedos sujos - sua honra manchada... Por essas e outras, paulatinamente, a escolarização transforma a criança em aluno (Patto, 1999, passim).

Depois da lição do professor, o exercício da classe (Chartier, 1995, passim): o decurião deveria recordar a dinâmica da mesma aula, fazendo exercícios que pudessem fixar na memória dos alunos o que foi aprendido. 0 decurião - por exemplo - ditaria palavras; os alunos deveriam repeti-las de cor; depois diriam as letras de que a palavra ditada era composta. 0 decurião ditava outra vez a palavra e só nessa ocasião é que os alunos iriam escrevê-las nas ardósias ou em papel comum. Terminada a lição de ditado, o decurião mandará os alunos trocarem entre si os papéis onde anotaram o que haviam escrito. Cada aluno poderia então corrigir a lição do colega para conferir se havia ali algum tipo de erro ortográfico. Havendo algum, o decurião mandaria o aluno reescrever corretamente a palavra, vinte vezes ou mais, para que pudesse de fato fixar na memória a emenda, e não o erro:

0 decurião deve pôr todo o cuidado em que os alunos não escrevam nunca uma palavra incorretamente, embora depois a emendem. A palavra que uma vez se escreveu errada fixa-se melhor na memória do que a palavra escrita corretamente. 0 dizerse que o aluno, vendo a palavra escrita cor- 
retamente, a decora logo e se esquecerá da errada, não é verdade; duas razões poderosas há para a memória reter com preferência o erro: a primeira, ter-se demorado mais tempo em escrever a palavra viciadamente do que em ver a emenda; segunda, o serlhe intuitiva a forma errada; porque foi dessa maneira que da primeira vez naturalmente a escreveu. (Aulete, 1873)

\section{Considerações finais}

Percebe-se, no decorrer da própria cartilha, o intento civilizatório nitidamente indicado. À escolarização caberá conferir hábitos: para as crianças e também para seus pais. Os alunos deveriam multiplicar os ensinamentos escolares em seus lares, de tal modo que, indiretamente, os pais pudessem também se beneficiar da escolarização e das visões e versões de mundo por ela apresentada. Como último parágrafo da Cartilha nacional, encontramos o seguinte:

(...) advertência importante: os pais devem auxiliar os esforços do professor, fazendo com que seus filhos copiem em casa a lição que deram na escola, interrogando-os depois sobre a significação de algumas palavras ou frases dessa mesma lição ou sobre qualquer outro assunto que lhes seja mui familiar para os exercitar a falar. (Aulete, 1873)

Muitos eram os relatos que induziam o aluno a comportamentos sociais que a escola valorizava: o asseio, a obediência, a disciplina, a polidez, o esforço e a perseverança. Quando a civilidade se apresenta como uma segunda natureza, de alguma maneira ela se amplia e passa a ser nomeada civilização dos costumes:

António é um menino atencioso e aplicado. Tira o boné quando encontra alguma pessoa conhecida, e fala-lhe com muito propósito. Quando lhe fazem algum favor, por pequenino que seja, agradece-o cortes- mente. Se pede alguma coisa, ainda que seja aos criados, junta sempre a seguinte frase: faz-me o favor. Quando é chegada a hora do estudo não necessita que ninguém lho lembre; se está brincando larga imediatamente o divertimento e vai estudar; não se levanta senão depois de saber a lição e de ter feito com muito asseio a sua escrita. É por isso que todos o estimam e não cessam de repetir: António é um excelente menino, muito cortês e um belo estudante. Ultimamente o pai comprou-lhe um lindo tambor com que António se diverte nas horas de recreio. (Aulete, 1873)

De todo modo, é nítido o intento de regrar o cotidiano pedagógico, quando, na última página daquele diretório, o autor compunha um modelo de horário - abaixo transposto - para distribuição das matérias de estudo no tempo exato da escolarização primária. Era já a grade curricular que parecia ser aqui arquitetada; a nova escola dos novos tempos que o século XIX visivelmente desejava instituir: um tempo rápido, eficaz, preenchido de maneira eficiente; um tempo, enfim, da produtividade laborial: tempos de civilização escolar como projeto cívico de organização do trabalho (Carvalho, 1986).

Para Caldas Aulete, o livro didático expressava, antes de tudo, uma possibilidade de contribuir para formar e orientar cotidianamente o professor a preparar sua aula. Sendo assim, o tempo é dividido, a matéria é dirigida, os exercícios e o próprio roteiro da aula eram sugeridos. Tal procedimento deveria trazer como efeito um aprimoramento nos níveis de êxito escolar em uma escola que era lenta no percurso do ensino do ler-escrever-contar. A mesma escola, aliás, deveria também ensinar a se comportar. A escola requer a formação do leitor; mas de um leitor comedido, disciplinado; não demasiadamente curioso pelo decifrar da cultura impressa. A mesma escola que ensina a ler ensina o quê deverá ser lido, como se deve ler, quanto e quando se deverá ler. 
A Cartilha - como primeiro livro do aluno - é o seu passaporte para a cultura das letras. Existe nisso um ritual de iniciação; um dado suporte simbólico de imagens do país - imagens essas que deverão ser decalcadas pela escola. Dessa maneira, supunha-se que a lógica da inscrição escolar conduziria, doravante, as vindouras gerações a retomarem o protagonismo português - perdido algures - no equilíbrio político e cultural europeu. 0 que submergira com a aventura das navegações - a suposta vocação do povo lusitano - caberia recuperar pela alavanca do mundo das letras. A escola primária auxiliaria o país a se reerguer, pela trilha do co- nhecimento. Era dever precípuo da civilização escolar auxiliar a construir esse país: um novo Portugal. Parecia imprescindivel àquele século XIX português abandonar, definitivamente, os devaneios e horizontes do Oceano para voltarse à terra; ao território da Península lbérica. Fazer isso requeria estudo. Além disso, havia de se projetar a identidade perdida; com o fito, inclusive, de tornar viável a elaboração de um relato de país suficientemente convicto e convincente para ser narrado às crianças. Esse talvez fosse o maior propósito das cartilhas de instrução primária: o de contar de um país às crianças...

Tabela: Horário de uma escola primária dividida em duas classes transcrita da $4^{a}$ edição.

\begin{tabular}{|c|c|c|c|c|c|}
\hline Horas & Segunda-feira & Terça-feira & Quarta - feira & Sexta feira & Sábado \\
\hline Das 8 às $8 \mathrm{~h} 45$ & princípios de leitura $P$ & desenho D & escrita D & desenho D & $\begin{array}{l}\text { princípios de } \\
\text { leitura } P\end{array}$ \\
\hline Das 9 às 9 h45 & escrita D & princípios de leitura $P$ & desenho D & contas D & escrita D \\
\hline Das10 às10h45 & ortografia D & ortografia D & $\begin{array}{l}\text { princípios de } \\
\text { leitura P }\end{array}$ & escrita D & ortografia D \\
\hline Das 11 às 11 h45 & desenho D & escrita D & contas D & $\begin{array}{l}\text { princípios de } \\
\text { leitura P }\end{array}$ & desenho D \\
\hline Das 2 às2h45 & $\begin{array}{l}\text { contas e sistema } \\
\text { métrico D }\end{array}$ & escrita D & desenho D & $\begin{array}{l}\text { conhecimentos } \\
\text { reais } P\end{array}$ & escrita D \\
\hline Das 3 às $3 \mathrm{~h} 45$ & escrita D & $\begin{array}{l}\text { conhecimentos reais } \\
\text { (as } 2 \text { classes) } P\end{array}$ & $\begin{array}{l}\text { exercícios de } \\
\text { falar } P\end{array}$ & ortografia D & $\begin{array}{l}\text { contas e sistema } \\
\text { métrico D }\end{array}$ \\
\hline Das 4 às $4 h 45$ & religião $\mathrm{P}$ & $\begin{array}{l}\text { exercícios de falar } \\
\text { (as } 3 \text { classes) } P\end{array}$ & $\begin{array}{l}\text { ginástica } \\
\text { (as } 2 \text { classes) P }\end{array}$ & $\begin{array}{l}\text { religião } \\
\text { (as } 2 \text { classes) P }\end{array}$ & $\begin{array}{l}\text { recitação } \\
\text { (as } 2 \text { classes) P }\end{array}$ \\
\hline Das 8 às $8 \mathrm{~h} 45$ & desenho D & desenho D & escrita D & Leitura corrente $\mathrm{P}$ & escrita D \\
\hline Das 9 às 9 h45 & leitura corrente $\mathrm{P}$ & escrita D & leitura P & escrita D & desenho D \\
\hline Das10 às10h45 & escrita D & ortografia D & ortografia D & gramática P & leitura corrente $P$ \\
\hline Das11 às11h45 & gramática P & leitura P & desenho D & problemas D & gramática $P$ \\
\hline Das 2 às $2 \mathrm{~h} 45$ & $\begin{array}{l}\text { aritmética no } \\
\text { quadro } P\end{array}$ & problemas D & $\begin{array}{l}\text { sistema métrico } \\
\text { no quadro } \mathrm{P}\end{array}$ & desenho D & aritmética $\mathrm{P}$ \\
\hline Das 3 às 3 h45 & problemas D & $\begin{array}{l}\text { conhecimentos reais } \\
\text { (as2classes) P }\end{array}$ & problemas D & ortografia D & problemas D \\
\hline Das 4 às $4 h 45$ & $\begin{array}{l}\text { religião (assiste } \\
\text { a } 1{ }^{a} \text { classe) P }\end{array}$ & $\begin{array}{l}\text { exercícios de falar } \\
\text { (as } 2 \text { classes) P }\end{array}$ & $\begin{array}{l}\text { ginástica } \\
\text { (as } 2 \text { classes) P }\end{array}$ & $\begin{array}{l}\text { religião } \\
\text { (as } 2 \text { classes) P }\end{array}$ & $\begin{array}{l}\text { recitação } \\
\text { (as } 2 \text { classes) P }\end{array}$ \\
\hline
\end{tabular}

Fonte: (Aulete, 1873)

Obs.: Os primeiros horários, compreendidos das 8 h às 4 h45, correspondem às matérias previstas para a $1^{\text {a }}$ classe. Os horários das linhas de baixo, compreendidos também entre $8 \mathrm{~h}$ e $4 \mathrm{~h} 45$, correspondem às matérias previstas para a $2^{\mathrm{a}}$ classe.

Legenda:

P - Esta letra significa que as lições hão de ser dirigidas pelo professor.

D - Esta letra significa que as lições hão de ser dirigidas por um decurião com a ajuda de um professor.

N. B. - Os exercícios feitos com as duas classes reunidas podem-se prolongar além dos 45 minutos. 


\section{Referências bibliográficas}

AULETE, F.J. C. Cartilha Nacional: methodo legographico para aprender simultaneamente a ler, escrever, ortographar e desenhar. 4. ed. Lisboa: Imprensa Nacional, 1873.

Selecta Nacional: curso pratico de litteratura portugueza. Lisboa: Typographia da Academia Real das Sciencias, 1882.

Livro da infância ou methodo facil e racional para ensinar o ler. Lisboa: Arquivo Nacional da Torre do Tombo, 1850. (MR Mç 3527 - Ofício dirigido ao Secretário do Conselho Superior de Instrução Pública apresentando a novidade da obra que então era lançada).

AULETE, F. J. C.; COELHO, J. M. L. Encyclopedia das escolas d'instrucção primaria. Lisboa: Typographia Universal, 1854.

BARROS, J. de. Grammatica da língua portuguesa com os mandamentos da Santa Madre Igreja. Rio de Janeiro: Fundação Biblioteca Nacional/Departamento Nacional do Livro, 1996. Edição fac-similar.

BITTENCOURT, C. M. F. Livro didático e conhecimento histórico. 1993. 369 p. Tese (Doutorado)- Faculdade de Filosofia, Letras e Ciências Humanas da Universidade de São Paulo, São Paulo, 1993.

CARVALHO, M. M. C. Molde nacional e forma cívica: higiene, moral e trabalho no projeto da Associação Brasileira de Educação (1924-1931). 1986. Tese (Doutorado)- Faculdade de Educação da Universidade de São Paulo, São Paulo, 1986. Mimeografado.

CATANI, D. Educadores à meia-luz. 1990. Tese (Doutorado)- Faculdade de Educação da Universidade de São Paulo, São Paulo,1990. Mimeografado.

CHARTIER, A. M. Les faires ordinaires de la classe: un enjeu pour la recherche et pour la formation. São Paulo: FEUSP, 1995. Mimeografado.

FERNANDES, R. Os caminhos do ABC: sociedade portuguesa e ensino das primeiras letras. Porto: Porto Editora, 1994.

ELIAS, N. 0 processo civilizador. Rio de Janeiro: Zahar, 1993. v. 2.

FIGUEIREDO, A. C. B. de. Logares selectos dos clássicos portugueses nos principais gêneros de discurso em prosa para uso das escolas. 16. ed. Coimbra: Imprensa da Universidade, 1879.

GOMES, J. F. (Org.) Relatórios do conselho superior de instrução pública (1844-1859). Lisboa: INIC, 1985.

HÉBRARD, J. A escolarização dos saberes elementares na época moderna. Teoria e Educação. Porto Alegre, p. 65-109,1990.

MIDOSI, L. F. 0 expositor portuguez ou rudimentos do ensino da língua materna. 4. ed. Lisboa: Imprensa Nacional, 1846.

MONTEVERDE, E. A. Manual encyclopedico para uso das escolas d'instrução primária. 4. ed. Lisboa: Imprensa Nacional, 1843.

Methodo facillimo para aprender a ler tanto a letra redonda como a manuscrita no mais curto espaço de tempo.

7. ed. Lisboa: Imprensa Nacional, 1859.

MINISTÉRIO DO REINO Inspecção das escolas públicas e particulares do distrito de Portalegre: classificação de alunos, disciplinas, mobiliário, etc. Lisboa: Arquivo Nacional da Torre do Tombo, 1867. MR n.1056.

NÓVOA, A. (Dir.) Dicionário de educadores portugueses. Porto: Asa, 2003.

. Le temps des professeurs. Lisboa: Imprensa Nacional, 1987 (v. I e II). 
PATTO, M. H. de S. A produção do fracasso escolar: histórias de submissão e rebeldia. São Paulo: Casa do Psicólogo, 1999.

RODRIGUES DE GUSMÃO, F. A. Estado da instrucção primária no concelho de Alpedrinha no ano lectivo de 1848-1849. Revista Universal Lisbonense. ano 9, 2. série, tomo II, 1849. p. 491.

TORRES, J. de Instrução elementar. 0 Panorama: jornal litterario e instructivo da sociedade propagadora dos conhecimentos úteis, Lisboa, $2^{\circ}$ da terceira série, 1853.

Recebido em 21.10.04

Aprovado em 03.11.04

Carlota Boto é licenciada em Pedagogia e em História pela Universidade de São Paulo. É mestre em História e Filosofia da Educação pela Feusp e doutora em História Social pela FFLCH-USP. É professora da área de Filosofia da Educação da Faculdade de Educação da USP. 